AL IBTIDA: JURNAL PENDIDIKAN GURU MI (2018) Vol 5 (1) : 95-106

DOI: http://dx.doi.org/ 10.24235/al.ibtida.snj.v5i1.2727

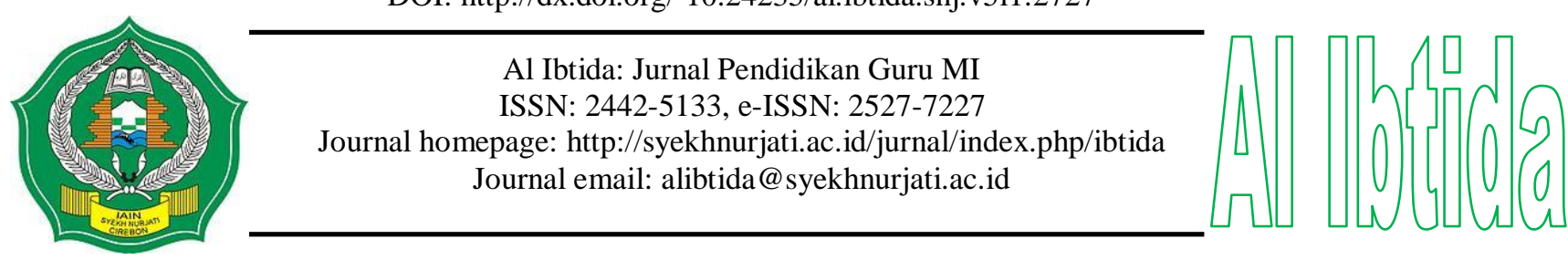

\title{
Penerapan Pembelajaran Tematik Berbasis Budaya Betawi untuk Meningkatkan Logical Intelligence Siswa SD Islam Taman Qur'aniyah Jakarta Selatan
}

\author{
Fery Muhamad Firdaus* \\ *Program Studi Pendidikan Guru Madrasah Ibtidaiyah, Fakultas Ilmu Tarbiyah dan Keguruan, \\ UIN Syarif Hidayatullah Jakarta \\ Email: fery.firdaus@uinjkt.ac.id \\ Nurul Badriyah** \\ **Program Studi Pendidikan Guru Madrasah Ibtidaiyah, Fakultas Ilmu Tarbiyah dan Keguruan, \\ UIN Syarif Hidayatullah Jakarta \\ Email: nurul.badriyah14@mhs.uinjkt.ac.id
}

Received 25 May 2018; Received in revised form: 04 June 2018; Accepted 08 June 2018

Publish Online: 29 June 2018

\begin{abstract}
Abstrak
Pada dasarnya seorang siswa memiliki banyak kecerdasan. Salah satu diantaranya adalah kecerdasan logika. Namun faktanya kecerdasan logika siswa SD Islam Taman Qur'aniyah masih rendah. Salah satu penyebabnya adalah karakteristik siswa yang berbeda-beda dan penggunaan strategi pembelajaran yang kurang inovatif. Penelitian ini bertujuan untuk: (1) mengetahui proses pembelajaran tematik berbasis budaya Betawi, dan (2) meningkatkan kecerdasan logika siswa kelas IV SD Islam Taman Qur'aniyah melalui pembelajaran tematik berbasis budaya Betawi. Penelitian ini menggunakan metode Penelitian Tindakan Kelas (PTK). Metode ini dilakukan dengan empat tahap, yaitu perencanaan, implementasi tindakan, pengaruh implementasi monitor, dan survei/refleksi. Teknik pengumpulan data yang digunakan adalah wawancara, observasi aktvitas guru dan siswa, tes kecerdasan logika, catatan lapangan, dan dokumentasi. Subjek dalam penelitian ini adalah siswa kelas IV SD Islam Taman Qur'aniyah yang berjumlah 27 siswa. Penelitian ini dilaksanakan melalui 3 siklus. Data yang diperoleh kemudian dianalisis menggunakan nilai persentase hasil tes kecerdasan siswa. Hasil Penelitian ini menunjukkan bahwa persentase hasil tes kecerdasan logika yang diperoleh pada siklus I sebesar $41 \%$ siswa dengan nilai rata-rata 57. Sementara itu pada siklus II meningkat menjadi $70 \%$ siswa dengan nilai rata-rata 69 dan kembali meningkat hingga mencapai $85 \%$ siswa pada siklus III dengan nilai rata-rata 77 . Dengan demikian dapat disimpulkan bahwa penerapan pembelajaran tematik berbasis budaya Betawi dapat meningkatkan kecerdasan logika siswa.
\end{abstract}

Kata kunci: pembelajaran tematik, budaya betawi, kecerdasan logika

\section{Abstract}

Basiclly a student has a lot of intelligence. One of them is logical intelligence. But in fact the logical intelligence of islamic elementary school's students of Qur'aniyah is still low. One of the causes is, the characteristics of different students, and the use of less innovative learning strategies. This study aims to: (1) to know the thematic teaching 
process based on Betawi culture, and (2) to improve the logical intelligence of fourth grade students of Islamic Elementary School Quraniyah through Betawi based thematic learning. This research uses Class Action Research method (PTK). This method is done with four stages, namely planning, action implementation, influence of monitor implementation, and survey/reflection. Data collection techniques used is interview, teacher's and student's activity observation, logic intelligence test, field notes, and documentation. The subjects of the study were the fourth graders of Islamic Elementary School Quraniyah which amounted to 27 students. This study was conduct for 3 cycles. Data obtained then analyzed using percentage value of students intelligence test results. The results of this study indicate that the percentage of logic intelligence test results obtained in the first cycle by $41 \%$ of students with an average value of 57 . Meanwhile in cycle II increased to $70 \%$ of students with an average value of 69 and again increased to $85 \%$ of students in cycle III with an average value of 77 . Thus can it is concluded that the implementation of thematic learning based on Betawi culture can improve the logical intelligence of students.

Keywords: thematic learning, betawi culture, logical intelligence

\section{PENDAHULUAN}

Pendidikan merupakan perhatian yang utama dan pertama dalam rangka menciptakan sekaligus meneruskan kehidupan dari generasi ke generasi sejalan dengan perkembangan zaman dan teknologi yang semakin canggih dan moderen. Pendidikan dalam Undang-Undang Negara Republik Indonesia No. 20 Tahun 2003 tentang sistem pendidikan nasional dijelaskan bahwa "Pendidikan adalah usaha sadar dan terencana untuk mewujudkan suasana belajar dan proses pembelajaran agar peserta didik secara aktif mengembangkan potensi dirinya untuk memiliki kekuatan spiritual keagamaan, pengendalian diri, kepribadian, kecerdasan, akhlak mulia, serta keterampilan yang diperlukan dirinya, masyarakat, bangsa, dan Negara" (Diknas, 2003). Indonesia memiliki banyak sumber daya alam, bahasa, serta suku dan budaya. Kita sudah tidak asing dengan suku Betawi. Suku Betawi merupakan sebutan untuk para penghuni daerah Jakarta dan sekitarnya, suku ini banyak dikenal karena letaknya berada di pusat pemerintahan Negara Republik Indonesia. Beberapa penelitian tentang masyarakat Betawi mengatakan bahwa kebudayaan Betawi sarat akan pengaruh dari Belanda, Cina, Arab, India, Portugis, dan Sunda (Purbasari, 2010). Penyelenggaraan pendidikan di Indonesia tidak dapat dipisahkan dari identitas-identitas yang melekat, seperti identitas etnik, kultur dan budaya.

Manusia dikatakan sebagai makhluk yang paling cerdas, dan Tuhan melengkapi manusia dengan komponen kecerdasan yang paling kompleks. Sebagaimana Allah SWT berfirman dalam Q.S. At-Tin ayat 4 yang artinya: "Sesungguhnya Kami telah menciptakan manusia dalam bentuk yang sebaik-baiknya”. Manusia sebagai makhluk ciptaan Tuhan yang paling sempurna. Secara fisik, manusia memiliki struktur tubuh yang sangat sempurna, ditambah lagi dengan pemberian akal. Akal yang dianugrahkan kepada manusia memiliki tingkatan kecerdasan yang berbedabeda. Kecerdasan tidak jauh dari akal dan berpikir. Allah berfirman dalam surat Ali-Imran ayat 
190-191 yang artinya: "Sesungguhnya dalam penciptaan langit dan bumi, dan silih bergantinya malam dan siang terdapat tanda-tanda bagi orang-orang yang berakal. (yaitu) orang-orang yang mengingat Allah sambil berdiri atau duduk atau dalam keadaan berbaring dan mereka memikirkan tentang penciptaan langit dan bumi (seraya berkata); 'Ya Tuhan Kami, Tiadalah Engkau menciptakan ini dengan sia-sia, Maha suci Engkau, Maha peliharalah Kami dari siksa neraka". Ayat tersebut menjelaskan bahwa Allah SWT telah menganugerahkan nikmat terbesar kepada manusia, yakni akal dan potensi berpikir yang membuat manusia berbeda dengan binatang. Oleh sebab itu, akal yang kita miliki seharusnya digunakan dan dikembangkan dan ditingkatkan untuk mempelajari ilmu-ilmu pengetahuan. Dengan akal dan kecerdasannya manusia mampu memecahkan permasalah hidup yang dihadapi dari yang sederhana sampai yang kompleks.

Pakar psikologi Gardner membagi kecerdasan menjadi 8, yaitu: (1) Kecerdasan linguistik, yakni kepekaan pada makna dan susunan kata; (2) Kecerdasan logika matematika, yakni kemampuan untuk menangani relevansi/argumentasi serta mengenali pola dan urutan; (3) Kecerdasan musikal, yakni kepekaan terhadap pola titinada, melodi irama, dan nada; (4) Kecerdasan kinestetis tubuh, yakni kemampuan untuk menggunakan tgubuh dengan terampil dan memegang objek dengan cakap; (5) Kemampuan spasial, yakni kemampuan untuk mengindra dunia secara akurat dan menciptakan kembali atau mengubah aspek-aspek dunia tersebut; (6) Kecerdasan naturalis, yakni kemampuan untuk mengenali dan mengklasifikasi aneka spesies, flora dan fauna, dalam lingkungan; (7) Kecerdasan interpesonal, yakni kemampuan untuk memahami orang dan membina hubungan; (8) Kecerdasan intrapersonal, yakni akses pada kehidupan emosional diri sebagai sarana untuk memahami diri sendiri dan orang lain (Hoerr, 2007). Kecerdasan logika matematis melibatkan banyak komponen, diantaranya (1) Perhitungan secara matematis, (2) Berpikir logika, (3) Pemecahan masalah, (4) Pertimbangan deduktif atau induktif, dan (5) Ketajaman pola-pola dan hubungan (Gardner, 2003). Ciri-ciri kecerdasan ini, diantaranya anak-anak yang berpikir dengan alasan/pemikiran/penalaran; mencintai eksperimen, pertanyaan, pemecahan masalah, teka-teki logika, dan berhitung; membutuhkan bahan untuk bereksperimen, ilmu material, manipulatif, perjalanan ke museum ilmu pengetahuan (Armstrong, 2013).

Dalam pembelajaran tematik memuat kompetensi untuk mengasah kemampuan tersebut. Herlianti menyatakan, "Pembelajaran tematik didasarkan pada sebuah tema sentral sebagai pengait beberapa mata pelajaran yang diajarkan, dengan kata lain pembelajaran tematik mengaitkan beberapa mata pelajaran dalam satu payung tema (Herlianti, 2015). Pembelajaran tematik lebih menekankan pada keterlibatan siswa dalam proses belajar secara aktif dalam proses pembelajaran, sehingga siswa dapat memperoleh pengalaman langsung dan terlatih untuk dapat 
menemukan sendiri berbagai pengetahuan yang dipelajarinya. Melalui pengalaman langsung siswa akan memahami konsep-konsep yang mereka pelajari dan menghubungkannya dengan konsep lain yang telah dipahaminya. Maka dari itu, pembelajaran tematik mempunyai kaitan dengan kecerdasan matematis-logika karena berhubungan dengan kemampuan siswa dalam memecahkan masalah, menghubungkan dengan konsep lain, serta berpikir secara logika.

Kecerdasan logika beberapa siswa di Sekolah Dasar Islam Taman Quraniyah belum sesuai dengan yang diharapkan (masih rendah). Hal ini diperkuat berdasarkan hasil observasi awal pada tanggal 12 Maret 2018 yang menunjukkan bahwa siswa kurang senang bekerja dan bermain dengan angka-angka, belum mampu menyelesaikan dengan baik jenis tes berpikir logik. Salah satu penyebabnya diantaranya, karakteristik siswa yang berbeda-beda, penggunaan strategi pembelajaran dan media yang kurang inovatif sehingga kesulitan dalam menghubungkan keterkaitan konsep yang mengakibatkan malas untuk berpikir. Jika hal tersebut dibiarkan terusmenerus, maka akan berdampak dengan kecerdasan yang dimiliki siswa tidak mencapai rata-rata.

Berdasarkan penelitian yang dilakukan Dwi Safitri Munjiani, ditemukan bahwa terdapat pengaruh kecerdasan logis matematis tinggi dan rendah terhadap hasil belajar matematika sebesar 90,1\% (Mujiani, 2016). Penelitian yang dilakukan Saliman diperoleh bahwa pemanfaatan budaya lokal dalam pembelajaran merupakan salah satu alternatif bentuk perancangan pembelajaran yang kreatif, yang pada gilirannya diharapkan dapat meningkatkan prestasi belajar (Saliman, 2007). Begitu pula dengan penelitian yang dilakukan Roikha, diperoleh bahwa kecerdasan matematis logis berpengaruh terhadap prestasi belajar. Artinya semakin tinggi kecerdasan siswa maka prestasi belajar siswa semakin tingggi pula dan juga sebaliknya (Roikha, 2017).

Berdasarkan uraian di atas, penulis tertarik untuk melaksanakan Penelitian Tindakan Kelas dengan judul "Penerapan Pembelajaran Tematik Berbasis Budaya Betawi untuk Meningkatkan Logical Intelligence Siswa SD Islam Taman Quraniyah”. Penelitian ini bertujuan untuk mengetahui implementasi pembelajaran tematik berbasis budaya Betawi dalam meningkatkan logical intellegence siswa di kelas IV serta mengetahui adanya peningkatan logical intellegence setelah diterapkan pembelajaran tematik berbasis budaya Betawi.

\section{METODE PENELITIAN}

Metode penelitian yang digunakan adalah metode penelitian tindakan kelas (PTK) atau classroom action research, yaitu penelitian tindakan (action research) yang dilakukan dengan tujuan memperbaiki pembelajaran di kelas. Dengan menggabungkan batasan pengertian tiga kata inti, yaitu: (1) penelitian, (2) tindakan, dan (3) kelas, penelitian tindakan kelas merupakan suatu pencermatan terhadap kegiatan belajar berupa sebuah tindakan yang sengaja dimunculkan dan 
terjadi dalam sebuah sebuah kelas secara bersamaan (Suharsimi, 2008). Menurut Gunawan, "action research adalah kegiatan dan atau tindakan perbaikan sesuatu yang perencanaan, pelaksanaan, dan evaluasinya digarap secara sistematik sehingga validitas dan relibilitasnya mencapai tingkat riset". Penelitian ini merupakan suatu penelitian yang mengangkat masalahmasalah aktual yang dihadapi oleh guru di lapangan. John Penelitian tindakan kelas adalah penelitian tindakan sebagai metode bagi guru untuk meakukan penelitian di dalam kelas sekaligus sebagai perancangnya (Trianto, 2012). Dengan melakukan penelitian tindakan kelas, guru memiliki peran ganda, yaitu sebagai praktisi dan peneliti.

Desain penelitian ini menggunakan metode John Elliot, dirancang untuk dapat menyelesaikan satu pokok bahasan yang dilaksanakan secara berkelanjutan dengan menggunakan tiga siklus. Setiap siklus dilakukan sesuai dengan perubahan atau perbaikan pembelajaran yang ingin dicapai. Model PTK dari John Elliot ini lebih rinci karena di dalam setiap siklus terdiri dari bebrapa aksi, yaitu anatar tiga aksi (tindakan). Sementara itu, setiap tindakan kemungkinan terdiri dari beberapa langkah yang terealisasi dalam bentuk kegiatan belajar-mengajar. Dalam penelitian ini peneliti menggunakan tiga siklus, setiap siklus terdiri dari empat tahap, yaitu: (1) Perencanaan; (2) Tindakan; (3) Observasi/Pengaruh; (4) Survei/Refleksi (Trianto, 2012).

Pertama, tahap perencanaan. Dalam tahap ini peneliti menjelaskan tentang apa, mengapa, kapan, dimana, oleh siapa, dan bagaimana tindakan tersebut dilakukan. Kegiatan ini meliputi menyusun perencanaan pembelajaran, mempersiapkan media pembelajaran, menyusun lembar observasi, mendesain alat evaluasi. Kedua, tahap pelaksanaan/implementasi tindakan. Pelaksanaan tindakan yang dilaksanakan dalam tahapan ini adalah melakukan kegiatan pembelajaran sebagaimana yang telah direncanakan, proses pembelajaran terbagi menjadi beberapa siklus disesuaikan dengan besarnya permasalahan yang harus dipecahkan. Pada ketiga siklus, pelaksanaan pembelajaran menggunakan pembelajaran tematik berbasis budaya Betawi. Observasi dilakukan dengan cara pengamatan langsung. Hasil pengamatan dijadikan refleksi untuk rencana tindakan pada siklus selanjutnya yang dilakukan oleh kolaborator atau peneliti yang terkait dengan suatu penelitian tindakan kelas yang dilaksanakan. Ketiga, tahap pengaruh implementasi monitor. Tahap ketiga yaitu selama tahap pelaksanaan pengamatan mengobservasi keaktifan dan respon siswa terhadap rencana pembelajaran yang telah di buat oleh peneliti. Dengan menggunakan lembar observasi peneliti mengamati peristiwa yang terjadi di kelas peneltian. Keempat, tahap survei/refleksi. Pada tahap ini adalah upaya evaluasi yang dilakukan oleh peneliti yang terkait dengan suatu penelitian tindakan kelas yang dilaksanakan. Refleksi ini dilakukan dengan cara kolaboratif yaitu adanya diskusi terhadap berbagai maslah yang terjadi dalam kelas penelitian. Dengan demikian, refleksi dapat dilakukan sesudah adanya implementasi 
tindakan dan hasil observasi. Berdasarkan hasil yang di dapat dari tahap observasi, dikumpulkan dan dianalisis bersama oleh peneliti dan observer. Hasil analisis tersebut digunakan sebagai acuan untuk merencanakan siklus selanjutnya.

Tempat penelitian ini dilaksanakan di SD Islam Taman Quraniyah Jakarta Selatan, dengan waktu penelitian dilakukan selama satu bulan dimulai dari bulan Maret hingga April 2018 pada tahun ajaran 2017/2018. Subjek penelitian adalah siswa kelas IV SD Islam Taman Quraniyah yang berjumlah 27 anak, terdiri dari 14 perempuan dan 13 laki-laki. Teknik pengumpulan data menggunakan instrumen hasil wawancara, hasil observasi aktvitas guru dan siswa, tes kecerdasan logika, catatan lapangan, dan dokumentasi. Untuk menganalisis setiap kecerdasan digunakan teknik analisis secara deskriptif dengan rumus sebagai berikut:

$$
P=\frac{f}{s} \times 100 \%
$$

Keterangan:

$\mathrm{P}=$ persentase kecerdasan siswa

$\mathrm{f}=$ frekuensi siswa yang mencapai nilai minimal (nilai 75)

$\mathrm{s}=$ jumlah siswa

\section{HASIL DAN PEMBAHASAN}

\section{A. Hasil Penelitian}

Pada pelaksanaan tindakan pembelajaran tematik berbasis budaya Betawi, peneliti melakukan proses pembelajaran tentang budaya Betawi, dengan budaya Betawi, melalui budaya Betawi, sekaligus melestarikan budaya Betawi. Salah satu diantaranya yaitu, menggunakan cerita-cerita rakyat dari daerah Betawi, permainan tradisional kuda bisik, serta menerapkan nilainilai yang dijunjung yakni kedisplininan, tolong-menolong dan bergotong-royong. Dapat dilihat minat, semangat, dan peningkatan siswa dalam belajar dengan penerapan pembelajaran ini.

Pada awal kegiatan pembelajaran guru selalu memulai dengan mengucapkan salam dan berdoa bersama. Setelah itu dilanjutkan dengan memeriksa kehadiran dan kesiapan siswa untuk belajar. Secara tidak langsung guru menyampaikan tujuan pembelajaran. Selanjutnya, guru melakukan apersepsi dengan memasukkan unsur budaya Betawi. Tanya jawab mengenai pengetahuan awal dengan mengaitkan budaya tersebut. Pembelajaran inti dimulai dengan memberikan siswa salah satu contoh cerita rakyat dari Betawi ataupun biografi salah satu budayawan Betawi.

Setiap fokus mata pelajaran disampaikan dengan mengaitkan unsur budaya tersebut. Sebagai contoh, melalui permainan kuda bisik, pembahasan keunikan kota Jakarta, dan sebagainya. Kemudian, memperdalamnya dengan tanya jawab secara individu maupunun klasikal. Saat pembelajaran berlangsung, guru memberikan tugas secara berkelompok. Siswa 
dapat menyelesaikan tugas tersebut dengan berdiskusi. Dari kegiatan diskusi diharapkan siswa menerapkan nilai-nilai yang dijunjung budaya Betawi, yakni bekerjasama, saling tolong menolong, dan bergotong-royong. Nilai kedisiplinan juga diperlihatkan saat tugas dikerjakan dan dikumpulkan tepat pada waktunya. Pembelajaran ditutup dengan menarik kesimpulan bersamasama. Tak lupa memberikan siswa kesempatan untuk bertanya terkait materi yang belum dipahami. Guru menutup dengan berdoa bersama dan mengucapkan salam.

Selain itu, peneliti dibantu oleh observer untuk mengobservasi aktivitas guru dan aktivitas siswa selama proses kegiatan belajar mengajar berlangsung. Observer mengobservasi aktivitas guru dan siswa, hasil observeri menunjukkan keberhasilan terhadap penerapan pembelajaran tematik berbasis budaya Betawi yang telah dilaksanakan pada kegiatan pembelajaran siklus I, II, dan III.

Berdasarkan data aktivitas guru diperoleh nilai 69 pada siklus I dengan kategori cukup, kemudian pada siklus II diperoleh nilai 76 dengan kategori baik, dan mendapatkan nilai 81 pada siklus III dengan kategori sangat baik. Sedangkan untuk data aktivitas siswa diperoleh nilai 61 pada siklus I dengan kategori cukup, kemudian pada siklus II diperoleh nilai 71 dengan kategori baik, dan mendapatkan nilai 76 pada siklus III dengan kategori baik. Peningkatan hasil observasi aktivitas guru dan siswa dari siklus I, siklus II, dan siklus III juga dapat disajikan dalam histrogram/grafik di bawah ini:

Grafik 1. Hasil Observasi Aktivitas Guru dan Siswa

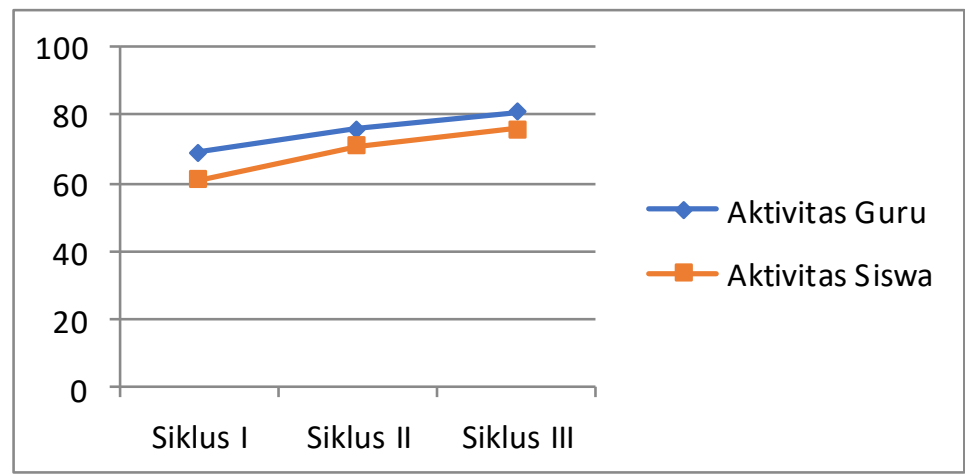

Penilaian dilakukan setelah tiga kali pertemuan. Indikator ketercapaian kecerdasan siswa pada penelitian ini yaitu apabila hasil persentase kecerdasan siswa lebih dari 75\% dengan kriteria mendapatkan nilai minimal 75 pada setiap tes. Peningkatan rata-rata hasil dari tes kecerdasan logika siswa dari siklus I, siklus II, dan siklus III terdapat pada tabel berikut ini:

Tabel 1. Nilai Rata-Rata Kecerdasan Logika Siswa

\begin{tabular}{lc}
\hline \multicolumn{1}{c}{ Pelaksanaan } & Nilai Rata-Rata \\
\hline Siklus I & 57 \\
\hline Siklus II & 69 \\
\hline Siklus III & 77 \\
\hline
\end{tabular}


Berdasarkan tabel 1 terlihat bahwa nilai rata-rata kecerdasan logika siswa pada siklus I diperoleh nilai rata-rata 57, kemudian pada siklus II diperoleh nilai 69, dan pada siklus IIIdiperoleh nilai 76. Peningkatan rata-rata nilai kecerdasan logika siswa dari siklus I, siklus II, dan siklus III juga dapat disajikan dalam histrogram di bawah ini:

Grafik 2. Peningkatan Nilai Rata-Rata Kecerdasan Logika Siswa

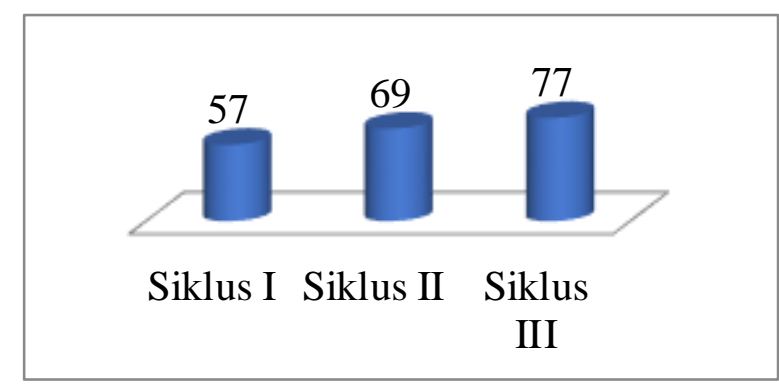

Dari histogram 2 di atas diketahui peningkatan nilai rata-rata kecerdasan logika siswa dari tindakan siklus I mendapatkan nilai 57 meningkat menjadi 69 sehingga mencapai 77. Adapun peningkatan persentase kecerdasan logika siswa pada siklus I, siklus II, dan III terdapat pada tabel di bawah ini:

Tabel 2. Persentase Kecerdasan Logika Siswa

\begin{tabular}{lc}
\hline \multicolumn{1}{c}{ Pelaksanaan } & Persentase \\
\hline Siklus I & $41 \%$ \\
\hline Siklus II & $70 \%$ \\
\hline Siklus III & $85 \%$ \\
\hline
\end{tabular}

Berdasarkan tabel 2 di atas terlihat bahwa persentase kecerdasan logika siswa pada siklus I sebesar $41 \%$ dari jumlah siswa, kemudian pada siklus II diperoleh sebesar 70\%, dan pada siklus IIIdiperoleh sebesar 85\%. Peningkatan persentase kecerdasan logika siswa dari siklus I, siklus II, dan siklus III juga dapat disajikan dalam histrogram di bawah ini:

Grafik 3. Peningkatan Persentase Kecerdasan Logika Siswa

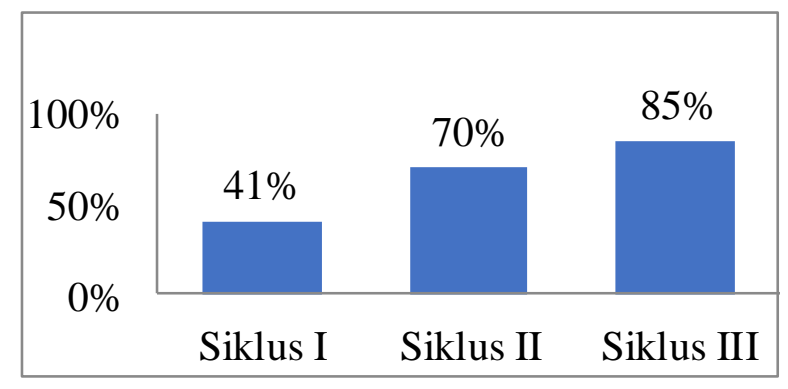

Dari histogram 3 di atas diketahui peningkatan persentase kecerdasan logika siswa dari tindakan siklus I sebesar $41 \%$ meningkat menjadi 70\% sehingga mencapai $85 \%$. 


\section{B. Pembahasan}

Keterkaitan antar konsep dengan tema sentral berdasarkan kehidupan real siswa, membuat pembelajaran tematik sangat relevan jika dikaitkan dengan budaya di sekitar, yaitu budaya Betawi. Sesuai dengan salah satu karakteristik pembelajaran tematik, yakni kontekstual karena tema yang diangkat berdasarkan kehidupan siswa (Herlianti, 2015). Pembelajaran Tematik adalah pembelajaran terpadu yang menggunakan tema sebagai pemersatu materi dalam beberapa mata pelajaran sekaligus dalam satu kali tatap muka. Hasil penelitian Sa'dun Akbar dkk menyatakan bahwa pembelajaran tematik layak dan valid dengan tingkat validitas yang bervariasi, dapat diterapkan dalam praktik pembelajaran sehari-hari di kelas, dan efektif dapat mencapai tujuan pembelajaran yang ditargetkan (Akbar \& Sutama, 2010).

Pada pelaksanaannya pembelajaran tematik melibatkan siswa sehingga menimbulkan kebermaknaan karena menggunakan tema yang berkaitan dengan kehidupan nyata dan dekat dengan kehidupan anak dan ada kaitannya dengan kehidupan sehari-hari. Sejalan dengan pandangan ini, Ausabel melalui teori pembelajaran bermakna (meaningful learning theory) menegaskan bahwa pembelajaran bagi peserta didik akan bermakna bila apa yang dipelajari oleh mereka berhubungan dengan apa yang diketahui dan dialaminya dengan kata lain kehidupan nyata (Sundayana, 2014). Impementasi pembelajaran tematik berimpilaksi dengan beberpa komponen, mencakup: guru, siswa, materi dan sumber belajar, sarana dan prasarana, penataan ruang, dan pemilihan metode (Sukini, 2012).

Piaget mengemukakan tahapan perkembangan kognitif pada anak usia (7-12 tahun) berada dalam tahap operasional kongkrit yang artinya pada tahap ini siswa mulai memiliki rasa ingin tahu yang tinggi dengan cara menyelidiki, mencoba, bereksperimen mengenai suatu hal yang dia anggap menarik bagi dirinya (Wafiqni \& Latip, 2015). Pada tahap ini anak mulai dapat menalar secara logis mengenai kejadian konkret dan mengklasifikasi objek ke latar yang berbeda. Pendapat ini berbeda dengan keadaan saat tindakan di lapangan, persentase siswa yang dapat menalar secara logis hanya $30 \%$ dari jumlah seluruh siswa.

Sesuai dengan tindakan yang telah dilaksanakan, peneliti merancang pengalaman belajar yang mengintergrasikan budaya Betawi sebagai bagian dari proses belajar mengajar, sehingga pelajaran tematik menjadi pelajaran yang sangat dinantikan. Pembelajaran Berbasis Budaya Betawi merupakan strategi penciptaan lingkungan belajar dan perancangan pengalaman belajar yang mengintegrasikan budaya sebagai bagian dari proses pembelajaran. Pembelajaran ini memiliki beberapa manfaat. Manfaat tidak hanya dirasakan oleh siswa, tetapi guru pun akan merasakan manfaat dari pembelajaran ini.

Dalam penerapannya pada siklus I, II, dan III guru menggunakan pembelajaran tematik berbasis budaya Betawi, sehingga tiap siklus siswa mengalami peningkatan. Pembelajaran 
berbasis budaya dibedakan menjadi empat macam, yakni belajar tentang budaya, belajar dengan budaya, belajar melalui budaya, dan belajar berbudaya. Budaya yang digunakan yakni budaya Betawi. Betawi merupakan suku yang sudah melekat pada kota Jakarta. Suku yang banyak dikenal karena letaknya berada di pusat pemerintahan Negara Republik Indonesia. Ada nilainilai yang dijadikan pedoman hidup antara lain, kedisplinan, gotong-royong, berbicara atau mendengarkan, dan sikap toleransi (Trafolta, Moch. Dimyati, \& Tjalla, 2015). Nilai-nilai tersebut sangatlah baik untuk dicontohkan sekaligus diterapkan siswa/i. Hal ini sesuai dengan hasil penelitian oleh Dina Triwinarni dkk bahwa kecerdasan logika berpengaruh terhadap kedisiplinan belajar siswa (Triwinarni, Fauzi, \& Monawati, 2017)

Dengan menggunakan pembelajaran berbasis budaya Betawi, budaya menjadi strategi pembelajaran bagi siswa untuk menstransformasikan hasil observasi mereka sehingga peran siswa bukan sekedar meniru atau menerima informasi saja, tetapi berperan sebagai penciptaan makna, pemahaman, dan arti dari informasi yang diperolehnya. Dapat dikatakan pemilihan strategi pembelajaran yang sangat penting. Hal tersebut dibuktikan oleh Nova Rozi dalam penelitiannya yang memilih permainan berhitung, penelitian tersebut menunjukan adanya peningkatan kecerdasan logika matematika anak (Rozi, 2012). Sama halnya dengan penelitian yang dilakukan Siti Chalihah yang memilih media kartu angka untuk mengembangkan kecerdasan logika matematika yang menunjukkan keberhasilan (Chalimah, 2015).

Dari penelitian yang dilakukan peneliti, pelaksanaan pembelajaran tematik dengan penerapan pembelajaran berbasis budaya Betawi telah sesuai dengan yang diharapkan. Sebagian besar siswa sudah berpartisipasi dalam pembelajaran. Hasil penelitian juga menunjukkan bahwa siswa dapat melaksanakan pembelajaran berbasis budaya dengan baik, sehingga kecerdasan siswa meningkat. Peneliti melihat peningkatan kecerdasan logika yang siswa miliki. Terlihat dari ciri-ciri yang dikemukakan Amstrong, yakni siswa lebih kepekaan terhadap pola-pola dan hubungan-hubungan yang logika, pertanyaan dan dalil (jika-maka, sebab-akibat), fungsi, dan abstrak terkait lainnya (Armstrong, 2013). Kecerdasan logika yang membuat siswa sering bertanya tentang berbagai fenomena yang dilihatnya. Dalam pelaksanaanya, mereka menuntut penjelasan logika dari setiap pertanyaan (Herlianti, 2015). Sejalan dengan Campbell yang mengemukakan bahwa kecerdasan logika matematis melibatkan banyak komponen, diantaranya: (1) Perhitungan secara matematis, (2) Berpikir logika, (3) Pemecahan masalah, (4) Pertimbangan deduktif atau induktif, dan (5) Ketajaman pola-pola dan hubungan.

Hasil penelitian yang dilakukan Masdiana dkk menunjukkan bahwa penerapan pembelajaran tematik dapat meningkatkan hasil belajar siswa di kelas 1 SD Negeri 018 Letawa (Masdiana, Budiarsa, \& Lamba, 2014). Sama hal nya dengan penelitian yang dilakukan oleh Hayama yang memperoleh peningkatan aktivitas belajar dengan mengimplementasikan 
pembelajaran temaik (Hayama, 2012). Peningkatan tersebut juga dirasakan peneliti. Berdasarkan hasil penelitian mulai dari siklus I, II, dan III dapat dijelaskan bahwa kecerdasan logika meningkat setelah penerapan pembelajaran tematik berbasis budaya Betawi. Peningkatan terlihat dari persentase tes kecerdasan logika yang diperoleh sebesar $41 \%$ memperoleh nilai rata-rata 57 pada siklus I setelah itu meningkat, sebesar 70\% diperoleh pada siklus II dengan rata-rata 69 sehingga mencapai $85 \%$ pada siklus III memperoleh nilai rata-rata 77

\section{SIMPULAN}

Berdasarkan uraian hasil penelitian di atas, dapat disimpulkan sebagai berikut:

1. Peneliti melakukan proses pembelajaran tentang budaya Betawi, dengan budaya Betawi, melalui budaya Betawi, sekaligus melestarikan budaya Betawi.

2. Berdasarkan hasil penelitian, analisis data, dan pembahasan, maka dapat disimpulkan bahwa kecerdasan logika siswa kelas IV SD Islam Taman Quraniyah meningkat karena penerapan pembelajaran tematik berbasis budaya Betawi. Hal ini dapat dilihat dari hasil observasi aktivitas guru dan siswa, dan hasil tes pada akhir setiap siklus.

3. Peningkatan kecerdasan logika siswa dapat terlihat dari hasil tes yang menunjukkan peningkatan persentase dari siklus I sebesar $41 \%$ dari jumlah siswa dengan nilai rata-rata 57, meningkat menjadi $70 \%$ diperoleh nilai rata-rata 69 sehingga mencapai $85 \%$ dengan nilai rata-rata 77.

\section{DAFTAR PUSTAKA}

Akbar, S., Sutama, \& Pujianto. (2010). Pengembangan Model Pembelajaran Tematik untuk Kelas 1 dan Kelas 2 Sekolah Dasar. Jurnal Pendidikan dan Pembelajaran, 17(1), 32-40.

Armstrong, T. (2013). Kecerdasan Multipel di Dalam Kelas Edisi Ketiga. Jakarta: PT Indeks.

Chalimah, S. (2015). Pegembangan Kecerdasan Logika Matematika dapat Ditingkatkan Melalui Media Kartu Angka Pada Anak TK Muslimat 2 Kemiri. Skripsi: Universitas Muhammadiyah Surakarta

Diknas, D. (2003). Undang-Undang Republik Indonesia No. 20 tentang Sistem Pendidikan Nasional. Jakarta: Direktorat Jendral Pendidikan Luar Sekolah dan Pemuda.

Gardner, H. (2003). Kecerdasan Majemuk: Teori dalam Praktek. Batam: Interaksara.

Hayama, Marzuki, \& Utami, S. (2013). Implementasi Pembelajaran Tematik untuk Meningkatkan Aktivitas Peserta Didik. Jurnal Pendidikan dan Pembelajaran, 2(3)

Herlianti, Y. (2015). Pembelajaran Tematik. Jakarta: UIN Press.

Hoerr, T. R. (2007). Buku Kerja Multiple Intelligences. Bandung: PT Mizan Pustaka.

Karli, H. (2010). Penerapan Pembelajaran Tematik untuk Mengembangkan Keterampilan Proses Sains di SD. Jurnal Pendidikan Penabur, 9(14), 44-57. 
Masdiana, Budiarsa, I. M., \& Lamba, H. A. (2014). Penerapan Pembelajaran Tematik untuk Meningkatkan Hasil Belajar IPA Materi pada Lingkungan Siswa Kelas I SDN 018 Letawa Kecamatan sarjo Kabupaten Mamuju Utara. Jurnal Kreatif Tadulako, 190-204.

Mujiani, D. S. (2016). Pengaruh Media Pembelajaran dan Kecerdasan Logis Matematis Terhadap Hasil Belajar Matematika Siswa. Jurnal Pendidikan Dasar, 7(2), 199-209.

Purbasari, M. (2010). Indahnya Betawi. 1-10.

Roikha, M. (2017). Pengaruh Kecerdasan Matematis-Logika dan Kecerdasan Visual-Spasial Terhadap Prestasi Belajar Matematika Materi Bangun Ruang Kelas V di SD Tamansiswa Turen.

Rozi, N. (2012). Peningkatan Kecerdasan Logika Matematika Anak Melalui Permainan Berhitung Menggunakan Papan Telur di TK Aisyiyah 7 Duri. Jurnal Pesona PAUD, 1(1) $1-10$.

Saliman. (2007). Penerapan Pembelajaran Berbasis Budaya Sebagai Upaya Peningkatan Kualitas Pembelajaran Pada Mata Kuliah Perencanaan Pembelajaran. Jurnal UNY.

Suharsimi. (2008). Penelitian Tindakan Kelas. Jakarta: Bumi Aksara.

Suhendri, H. (2011). Pengaruh Kecerdasan Matematis-Logis dan Kemandirian Belajar terhadap Hasil Belajar Matematika. Jurnal Formatif, 1(1), 29-39.

Sukini. (2012). Pembelajaran Tematik di Sekolah Dasar Kelas Rendah dan Pelaksanaannya. 5969.

Sundayana, W. (2014). Pembelajaran Berbasis Tema; Panduan Guru dalam Mengembangkan Pembelajaran Terpadu. Jakarta: Erlangga.

Trafolta, C. J., Moch. Dimyati, M., \& Tjalla, D. A. (2015). Empati Mahasiswa Etnis Betawi Program Studi Bimbingan dan Konseling pada Universitas Negeri Jakarta. Jurnal Insight, 4(1), 1-6.

Trianto. (2012). Model Pembelajaran Terpadu. Jakarta: PT Bumi Aksara.

Triwinarni, D., Fauzi, \& Monawati. (2017). Pengaruh Kecerdasan Logika Matematika terhadap Kedisiplinan Belajar Siswa Kelas V SD Negeri 1 Pagar Air Kabupaten Aceh Besar. Jurnal Ilmiah Pendidikan Guru Sekolah Dasar, 2(1), 16-29.

Wafiqni, N., \& Latip, A. E. (2015). Psikologi Perkembangan Anak Usia MiI/SD. Jakarta: UIN Press. 